Re/Claiming Bishkek: Contestation and Activism in the City of Two Revolutions

\author{
Schröder, Philipp ; Nasritdinov, Emil
}

Posted at the Zurich Open Repository and Archive, University of Zurich ZORA URL: https://doi.org/10.5167/uzh-149785

Journal Article

Published Version

Originally published at:

Schröder, Philipp; Nasritdinov, Emil (2017). Re/Claiming Bishkek: Contestation and Activism in the City of Two Revolutions. Central Asian Affairs, 4(2):97-128. 


\title{
Re/Claiming Bishkek: Contestation and Activism in the City of Two Revolutions
}

\author{
Emil Nasritdinov \\ Associate Professor, Anthropology, American University of Central Asia, \\ Kyrgyzstan \\ emilzn@gmail.com

\section{Philipp Schröder} \\ Humboldt-Universität zu Berlin, Institute for Asian and African Studies, \\ Germany \\ pschroeder@asa.hu-berlin.de
}

\begin{abstract}
In Kyrgyzstan, and especially in Bishkek, practices of social activism have been evolving and taken more meaningful and organized forms. Today, there are all kinds of activist groups and movements that are not simply struggling for resources, but feature solid ideological foundations and concrete visions. This introduction provides a brief overview of contemporary social activism in Bishkek.
\end{abstract}

\section{Keywords}

Kyrgyzstan - Bishkek - Tulip Revolution - contestation - activism

We have heard many tourists and visitors to Bishkek, the capital of Kyrgyzstan, say that they like the city very much. But when asked about what exactly they like, many get confused and have difficulty forming a strong answer. There is nothing special about Bishkek's architecture or its planning (compared to Astana, for example), and the city is quite dusty and crowded (compared with all other capitals in Central Asia). "Well, Bishkek is green," they remark, but considering how the city's oak trees have been blighted by insects recently, the more appropriate description now might be "Bishkek is brownish." 
One less tangible quality mentioned by visitors is the sense of freedom and the way they feel at ease in Bishkek, unlike in other Central Asian capitals. This is where the discussion becomes more interesting. Within Central Asia, Kyrgyzstan is often depicted as the "island of democracy in the sea of authoritarian states" with Bishkek then being the main "volcano" of this island-the turbulent "city of two revolutions" (in 2005 and 2010).

Many scholars, policymakers, and tourists are inspired by this image of Kyrgyzstan and its capital, while others are more skeptical and critical of it. In this collection of articles, we explore in more depth what such a sense of freedom might mean at the level of everyday practices among Bishkek residents. We will do so by looking at various contemporary forms of contestation and activism. In a city where the central government has less power or desire to control urban life, it is important to understand who claims the urban space today and what forms these claims take.

We start by reviewing some theoretical aspects of contestation and activism in the urban domain. Then we present some Soviet/post-Soviet and other binary academic discourses on urban Central Asia and follow this up with a brief analysis of the revolutions and social protests that have occurred in Bishkek. The empirical sections present vignettes of three social activist groups and gives an overview of the five articles included in this special issue. To conclude, we circle back to the theories and to Bishkek as a place in the wider academic discourses that extend beyond Central Asia and the post-Soviet space.

\section{Theories of Urban Contestation and Activism}

\section{Urban Segregation, Fragmentation, and Differences}

Perrone perceives the contemporary city as a field with a myriad of problems. ${ }^{1}$ Similarly, Lefebvre argues that cities have reached a critical point in their evolution and this crisis is global. ${ }^{2}$ The city is no longer the oeuvre - a work of art, but an instrument or device producing homogeneity, where the larger sum of elements replaces differences. Monotony and geometric isotopy produce mental and social misery, and all of that is due to economic rationality. Humanist ideology and utopia are subverted by segregations that are driven by the state

1 Camilla Perrone, "What Would a 'DiverCity' be like? Speculation on Difference-sensitive Planning and Living Practices," in Camilla Perrone, Gabriele Manella, and Lorenzo Tripodi (eds), Everyday Life in the Segmented City (Bingley, U K: Emerald Group Publishing, 2011), 1-26.

2 Henri Lefebvre, Writings on Cities (Oxford, uk, Blackwell, 1996). 
from above and private entrepreneurship from below. ${ }^{3}$ The animal spirit of capitalism and the political economy of mass dispossession based on predatory practices are at play here. ${ }^{4}$

According to Harvey, global urbanization today transforms life in the city and results in individual isolation, anxiety, and neurosis. ${ }^{5}$ Fincher and Jacobs also argue that cities produce a modern condition of alienation. ${ }^{6}$ Modern cities are divided, fragmented, and conflict-prone. This segregation destroys the urban, and the city as a specific institution disappears. It is reconstituted by the institutions of power via diverse measures, regulations, and constraints. ${ }^{7}$ The polarization of cities' social and political structures-a schism between rich and poor-produce spatial segregation, ${ }^{8}$ which in turn produces sociological, ecological, and formal ghettos. ${ }^{9}$ Doreen Massey analyzes how economic globalization produces new hierarchies of power and influence and new urban divides. ${ }^{10}$ However, she proposes that the urban division is grounded not just in the global and local socioeconomic conditions, but much deeper, in the way we think about space. She suggests that we see some spaces as masculine (universal, global, floating, generalizing, class, space) and others as feminine (local, private, home, nostalgia, nature, place). Taken together, such view of space as bounded, authentic, singular, and thus with fixed identities produces binary divisions and a structural thinking in dualisms and polarizations. This way of thinking is designed for dominance, and she argues that it must be challenged. ${ }^{11}$

First of all, the classic ecological model of the Chicago school, which perceived cities as comprised of segregated, homogenous zones, is hardly applicable anymore: on the one hand, we can find many wealthy gated communities located within poor suburbs, and, on the other hand, today there are many slums inside wealthy areas. Filho and Monteiro describe how this rendered

3 Lefebvre, Writings on Cities.

4 David Harvey, Rebel Cities: From the Right to the City to Urban Revolution (New York: Verso, 2012).

$5 \quad$ Harvey, Rebel Cities.

6 Jane Jacobs and Ruth Fincher, "Introduction," in Ruth Fincher and Jane Jacobs (eds), Cities of Difference (New York: Guilford, 1998), 1-25.

7 Lefebvre, Writings on Cities.

8 Loic Wacquant, Urban Outcasts: A Comparative Sociology of Advanced Marginality (Malden, MA: Polity, 2008).

$9 \quad$ Lefebvre, Writings on Cities.

10 Doreen Massey, Space, Place, and Gender (Minneapolis: University of Minnesota Press, 1994).

11 Massey, Space, Place, and Gender. 
the physical distance between disparate groups shorter, while their "socioeconomic distance" intensified. ${ }^{12}$ The result is a fragmentation of urban structures and the subdivision of segregated spaces. The city becomes a complex mosaic with social inequalities materialized within and between walls or fences. However, these walls are not always or eternally static and solid, but might become quite fuzzy and drifting. Urban spaces then can be grasped as networked territories, at the same time fragmented and connected through the dynamics of "flow spaces," i.e., "repetitive sequences of interchanges and interactions" that are "in the permanent process of change" and thus remain incomplete and contingent. ${ }^{13}$

Massey also puts forward the conceptualization of space and place as social relations, which makes it inherently dynamic. She suggests that how we imagine space has ramifications. ${ }^{14}$ Usually, we perceive space as a surface with people as objects on it, and we perceive places as closed, coherent, and integrated. Yet these might be failures of our spatial imagination, representing the "cosmology of one narrative" that "obliterates multiplicities." According to Massey, we need to refute these static visions and instead perceive space not as dead or fixed but as lively and alive. In this alternative view, space is a product of interrelations and is always under construction, i.e., quite literally always being made (materially and socially). This approach then can well be considered as anti-essentialist, because it acknowledges divergences and emphasizes the basic potential for solidarity.

This is a much more promising base to think about heterogeneous urbanities. Perrone understands the city based on an epistemology of multiplicity and the recognition of difference emanating from multiple interactions. ${ }^{15}$ The dual view of urban diversity produces fear of "the other," promotes practices to expel diversity, and results in a segmented city, where the poor or other marginal groups are isolated, while the rich and empowered hide inside gated communities. In contrast, the optimistic view on urban diversity, such as the one of DeCerteau, focuses on how complex organizational practices generate new and varied urbanities. In the ideal city that appreciates diversity,

12 M. Filho and C.M. Monteiro, "Segmented Cities with Fuzzy Walls: Changes in Informal Settlements as Seen Through a Multi-scale Analysis," in Camilla Perrone, Gabriele Manella, and Lorenzo Tripodi (eds), Everyday Life in the Segmented City (Bingley, uK: Emerald Group Publishing, 2011), 143-168.

13 Filho and Monteiro, "Segmented Cities with Fuzzy Walls."

14 Doreen Massey, For Space (Sage Publishing, 2005). Doreen Massey, "Cities in the World," in Doreen Massey, John Allen, and Steve Pile (eds), City Worlds (New York: Routledge, 2005), 93-150. 
knowledge belongs to the array of actors, and collaboration between actors does not always mean consensus-building because some opinions are irreconcilable. ${ }^{16}$ In that way, the contemporary city lost its (previously imagined) singularity; instead, it is polyphonic, fragmented, contradictory, and conflicting. ${ }^{17}$ However, this is to be understood as a positive heterogeneity working against essentialism and producing liveliness and complexity of space. Space should not be representative or synchronous, but heterogeneous, relational, coeval, and alive. ${ }^{18}$

Fincher and Jacobs accordingly suggest that thinking of differences along singular axes (e.g., gender, race, ethnicity, social status) is limited and leads to a hierarchical structuring of identities. ${ }^{19}$ Instead, we need to look at the combination of defining characteristics, subjectivities, and "discursively constituted identities." We need to focus on how various axes of differences are intertwined, and to properly understand this complex differentiation today we need a cross-fertilized field of theories, research paradigms, and methods from post-structuralism, feminism, postcolonial criticism, and psycho-analytical theory. Fincher and Jacobs ask: Is identity so easily attached to place? And the answer is: Not really. The city dwellers are not fully determined by structural conditions, nor are they outside of them: they are in-between, they constantly turn the gears of their identifications and occupy more than one system of differences and often more than one space at a time. ${ }^{20}$

\section{Right to the City and Social Movements}

Fincher and Jacobs also emphasize that places and spaces are not neutral stages and they are more than just containers: they are intertwined with social processes and relations. ${ }^{21}$ Space converts to place through contestations over identity. Jacobs defends the cultural politics of urban space that help articulate identities along multiple vectors of power. ${ }^{22}$ Unfortunately, according to Suyungedouw, the modern city is fading as an alive and thriving arena for

16 Perrone, "What Would a 'DiverCity' Be Like?"

17 Lorzeno Tripodi, "Everyday Life in the Segmented City: An Introduction," in Camilla Perrone, Gabriele Manella, and Lorenzo Tripodi (eds), Everyday Life in the Segmented City (Bingley, Uk: Emerald Group Publishing, 2011), xiii-xx.

18 Massey, 2005, see footnote 14 on previous page.

19 Jacobs and Fincher, "Introduction."

20 Jacobs and Fincher, "Introduction."

21 Jacobs and Fincher, "Introduction."

22 Jane Jacobs, "Staging Difference: Aestheticization and the Politics of Different in Contemporary Cities," in Ruth Fincher and Jane Jacobs (eds), Cities of Difference (New York: Guilford, 1998), 252-278. 
political encounter and democratic negotiation. ${ }^{23}$ It is colonized by technomanagerial policies; it has become post-political and post-democratic as managed by Foucauldian governmentality. In that reading, cities are designed by and for elites, embedded in transnational networks that advance neoliberal agendas of economic growth, competitiveness, and entrepreneurship. Such governmentality promotes a consensual system and eliminates disagreements by excluding those outside of such consensus, which, according to Suyungedouw, ${ }^{24}$ would mark the end of politics. A true political community, on the other hand, should be driven by an egalitarian logic that divides and produces interruptions, fractures, divisions, conflicts, disagreements, disorders, disaggregations, and dissensus. Yet today, such community is colonized by a "seeming politicization," which barely affects the police order, but in reality supports what it intends to subvert.

Mitchell argues that political engagement, struggle, and civic disobedience help to create the Just City, with the main barometer of justice being the handling of urban public spaces. ${ }^{25}$ In detail, he argues that anti-homelessness laws of contemporary urban regimes commodify public space, leading to a further stratification and marginalization, especially of a less-fortunate majority. Today, according to Harvey, the right to the city is confined to small groups of political and economic elites who reshape the city after their own agendas. ${ }^{26}$

As a response to such pressures, there are new trends in resistance emerging all around the world. Harvey calls them "insurgent citizenship" - movements that fight for the right to the city. They represent the heterotopy, i.e., the "result of everyday struggle and coming together of different groups," as opposed to isotopy, i.e., the "rational order of capitalism and state." Lefebvre describes the right to the city as a superior form of right: the right to freedom, individualization in socialization, oeuvre, participation, and appropriation. ${ }^{27}$ Purcell distinguishes two types of rights: for participation (central/direct role in decisionmaking) and appropriation (to access, occupy, use, and produce). ${ }^{28}$ Mitchell states that this right to the city is not given, it comes about from social struggle, unruly behavior, and violence, which often are understood as the only ways to

23 Erik Suyungedouw, Designing the Post-political City and the Insurgent Polis (London: Bedford Press, 2011).

24 Suyungedouw, Designing the Post-political City and the Insurgent Polis.

25 Don Mitchell, The Right to the City: Social Justice and the Fight for Public Space (New York: Guilford, 2003).

26 David Harvey, Rebel Cities: From the Right to the City to Urban Revolution (New York: Verso, 2012).

27 Lefebvre, Writings on Cities.

28 Mark Purcell, "Excavating Lefebvre: The Right to the City and Its Urban Politics of the Inhabitant," GeoJournal, 58, no. 3/4 (2002): 99-108. 
be heard. ${ }^{29}$ Space becomes public when social groups claim it through action in light of pressing needs. Public space is always contingent and by claiming space, groups become public.

Claiming the right to the city requires never taking that right for granted, never being satisfied with how it is for now "closed," how for now utopia has been materialized. Expanding the right to the city requires a clear focus on the utopic possibilities, and the dangers, of always seeking to reopen, and thus to reform, public space in the image of a more just order. ${ }^{30}$

Today, we can see the emergence of various social movements fighting for the right to the city. Pulido refers to Jesper, who defines a social movement as "conscious, concerted, and relatively sustained efforts by organized groups of ordinary people (as opposed to say, political parties, the military, or industrial trade groups) to change some aspects of their society by using extra-constitutional means." ${ }^{31}$ Categorizing social movements, Reiten places them on a continuum, where on the one side we can find feminists, anarchists, Marxists, and reformists (those who advocate the return to Keynesian economics), whereas on the other side there are skeptics, recovering neoliberals, and champion defenders of neoliberal capitalism. ${ }^{32}$ She suggests that contemporary leftist activism is changing: there is more shared information, networking, and coordinated actions, even at the transnational level. New cross-border networks are emerging and the "World Social Forum" could be considered a network of networks. The main idea that unites all these movements is the struggle for another possible world, against corporate power, poverty, environmental degradation, the feminization of poverty, erosion of democracy, and against the main institutions that would defend a neoliberal order-the World Bank, International Monetary Fund, World Trade Organization, and Structural Adjustment Programs, among others. ${ }^{33}$

Broadly speaking, global social movements can be divided into two types: radicals (who use transgressive tactics) and reformists (who employ contained tactics and conferences). Reiten suggests that today these types often conduct joint action against their main enemy—the global capitalist agenda. But at the same time, there is a growing diversity of goals, tactics, and organizational

\footnotetext{
29 Mitchell, The Right to the City.

$30 \quad$ Mitchell, The Right to the City, 236.

31 Laura Pulido, Black, Brown, Yellow, and Left: Radical Activism in Los Angeles (Los Angeles: University of California Press, 2006), 31.

32 Ruth Reiten, Global Activism: (New York: Routledge, 2007).

33 Reiten, Global Activism.
} 
structures that do not always overlap, cooperate, or converge. ${ }^{34}$ There are many radical groups that rely on riots to express their views. According to Wacquant, the majority of riots in the United States, United Kingdom, and France are driven by two logics: one against ethno-racial injustice and another against economic deprivation and widening social inequalities. ${ }^{35} \mathrm{He}$ describes these as mixed, with ethnic migrants and blacks fighting alongside whites advancing demands from working class youth: jobs, schools, fair police treatment, and decent housing.

Another kind of global social struggle is cultural activism. Firat and Kuryel define these groups as fighting for societal transformations by disturbing and reorienting the cultural-political sphere. ${ }^{36}$ That endeavor employs a great diversity of ideas and methods: jamming, sousvelience, media hoaxing, urban guerilla, ad busting, billboard liberation, hacktivism, subvertising, street art, and flash-mobs. The purpose of cultural activism is not to destroy, but to distort codes and signs of power. Such groups use creativity and imagination and they intermingle art, activism, politics, and performance. Yet, on the other "safer" end of the activist spectrum, there is the Cittaslow (Slow City) movement. Sarah Pink describes this as middle-class activism by urban residents in cooperation with city council members. ${ }^{37}$ This is not a form of protest activism, but rather activism oriented toward the community, which includes such activities as food festivals, carnivals, and farmers' markets. The main aim of the Cittaslow movement is to protect local identities, which is why it draws on specific place-based—not imaginary-communities. ${ }^{38}$ There are many other variants of activism: environmental, feminist, conservationist, design, and others. Together, these social movements aim to turn the city from a site of oppression back to the Lefebvrian city as oeuvre.

These theories and practices of social activism, urban diversity, and contestation help us establish a certain theoretical platform from which to move further. However, the cases and discussions reviewed so far were mostly grounded in a capitalist Western context. But how has the situation been different in Soviet and post-Soviet urban spaces and how might the Central Asian context make these

\footnotetext{
34 Reiten, Global Activism.

35 Wacquant, Urban Outcasts.

36 Beg Frrat and Aylin Kuryel, "Introduction: Cultural Activism: Practices, Dilemmas, and Possibilities," in Beg Firat and Aylin Kuryel (eds), Cultural Activism: Practices, Dilemmas, and Possibilities (Amsterdam: Rodopi, 2010), 9-20.

37 Sarah Pink, "Re-thinking Contemporary Activism: From Community to Emplaced Sociality," Ethnos, 73, no. 2 (June 2008): 163-188.

38 Pink, "Re-thinking Contemporary Activism."
} 
phenomena even more unique? We suggest starting in the same place where we began earlier: with a discussion of urban division and binary discourses.

\section{Soviet/Post-Soviet and Other Binary Academic Discourses on Urban Central Asia}

The most important academic binary division is temporal, and it divides Central Asian urban experiences into Soviet and post-Soviet. Almost all descriptions of Central Asian cities refer to their Soviet legacy and usually these references are positive and nostalgic. Darieva and Kaschuba describe the egalitarian urbanism of Soviet city: collective identity, modernity and progress, functional zoning, the system of micro-raions, and green spaces. ${ }^{39}$ Liu describes how Soviet administration aimed to transform Central Asia and mold a Soviet Central Asian person by "raising" their cultural and intellectual abilities, establishing industries and factories, and by transforming and administering traditional Central Asian societies. ${ }^{40}$ Nasritdinov, Gareeva, and Efremenko depict in detail the active social life of Soviet micro-districts. ${ }^{41}$ Suyarkulova and McBrien focus on the Soviet emancipation of Central Asian women. ${ }^{42}$ Flynn, Kosmarskaya, and Sabirova discuss their respondents' nostalgia for Soviet Frunze (Bishkek's Soviet-era name), referring to its aesthetics, cultural and industrial life, socialist urban order, and morality. ${ }^{43}$

This nostalgia is frequently compared to the despair caused by the postSoviet urban collapse and chaos, which produced deep emotional crises, where

39 Tsypylma Darieva and Wolfgang Kaschuba, "Sights and Signs of Postsocialist Urbanism in Eurasia: An Introduction," in Tsypylma Darieva, Wolfgang Kachuba, and Melanie Krebs (eds), Urban Spaces after Socialism: Ethnographies of Public Places in Eurasian Cities (Frankfurt: Campus Verlag, 2011).

40 Morgan Liu, Under Solomon's Throne: Uzbek Visions of Renewal in Osh (Pittsburgh, PA: University of Pittsburg Press, 2012).

41 Nasritdinov, Gareyeva and Efremenko, "How Small Kitchens Become Even Smaller: Social Life of Soviet Microdistricts," in Daou, Huppatz, and Dinh (eds), Unbounded: on the Interior and Interiority (Cambridge Scholars Publishingm, 2015).

42 Mohira Suyarkulova, "Fashioning the Nation: Gender and Politics of Dress in Contemporary Kyrgyzstan," Nationalities Papers, 44, no. 2 (2016): 247-265; Julie McBrien, "Mukadas's Struggle: Veils and Modernity in Kyrgyzstan," The Journal of the Royal Anthropological Institute, Vol. 15, Islam, Politics, Anthropology (2009), pp. S127-S144, Royal Anthropological Institute of Great Britain and Ireland.

43 Moya Flynn, Natalya Kosmarskaya, and Guzel Sabirova, "The Place of Memory in Understanding Urban Change in Central Asia: The Cities of Bishkek and Ferghana," Europe-Asia Studies, 66, no. 9, (2014): 1501-24. 
material collapse became a state of mind along with a decay of spirituality and moralities. ${ }^{44}$ Darieva and Kaschuba also give a compelling overview of postSoviet urbanism..$^{45}$ They describe how post-Soviet change resulted in the dismantling of the socialist order and the arrival of a hybrid mix of actors "inscribing their signs into the cityscape." According to these authors, three processes characterize post-Soviet urbanisms: a shrinking of public space, a new consumer culture, and an ethno-nationalization of urban life and city imaginaries.

Besides such binary divisions between Soviet and post-Soviet urban life, there are other forms of division as well. Post-Soviet cities in Central Asia are known for their divided nature regarding various kinds of claims and contestations, such as along the lines of ethnicity, urban-rural status, or language. According to Liu, urban places are never neutral; they define who belongs and who does not. ${ }^{46}$ He shows how Osh is described by its residents as a tale of two cities: an ancient city of mahallas (neighborhoods) versus a modern Soviet part of the city. The violent conflict in 2010 in Osh and other parts of southern Kyrgyzstan has further ethnicized territoriality and created shifting tactical battlegrounds and military geographies that are layered onto the cityscape. Kosmarsky depicts the evolution of urban division in Tashkent as one from the Tsarist city to a covert Soviet apartheid (of Uzbeks by Europeans) to a post-Soviet division where established Russians and other Slavs unite with urban Uzbeks against rural newcomers. ${ }^{47}$ Fehlings describes similar tensions between urbanites and newcomers in Yerevan. ${ }^{48}$ She details how long-term residents perceive contemporary Yerevan as a "village" because of the demise of urban culture and the inflow of rural migrants. It is interesting here that the mix of incoming rural migrants-ranging from wealthy "new Armenians" to very poor newcomers - is both feared and romanticized at the same time. These migrants in the (imaginary) category "rurals" tend to be associated with nature, which carries spiritual value, but they are also seen as a wild force that is dangerous and has to be tamed within the urban domain.

44 Joma Nazpary, "Post-Soviet Chaos: Violence and Dispossession in Kazakhstan," Pluto Press, 2002; Ferideh Heyat, "Re-Islamisation in Kyrgyzstan: gender, new poverty and the moral dimension," Central Asian Survey, 23, no. 3/4 (2004): 275-287; Susanne Fehlings, "The Ignoble Savage in Urban Yerevan," Central Asian Survey, 35, no. 2 (2016): 195-217.

Darieva and Kaschuba, "Sights and Signs of Postsocialist Urbanism in Eurasia: An Introduction."

46 Liu, Under Solomon's Throne.

47 Artyom Kosmarsky, "Grandeur and Decay of the 'Soviet Vyzantium': Spaces, Peoples, and Memories of Tashkent, Uzbekistan," in Tsypylma Darieva, Wolfgang Kachuba, and Melanie Krebs (eds), Urban Spaces after Socialism: Ethnographies of Public Places in Eurasian Cities (Frankfurt: Campus Verlag, 2011).

Fehlings, "The Ignoble Savage in Urban Yerevan." 
An urban-rural divide within the city is one of the most frequently discussed topics in Bishkek. Flynn and Kosmarskaya analyze how long-term residents construct the "rural other" in the city and attribute them with negative characteristics and essentialist stereotypes. ${ }^{49}$ The authors see the roots of such division in the Soviet inequalities between city and village: Soviet-inspired expectations of "culturedness" are contrasted with the supposed lack of culture (beskulturie) in the villages. Today, according to Flynn and Kosmarskaya, this division has gained greater socio-political significance. Urbanites have developed a phobia of ruralization and express an antagonism toward newcomers, perceiving them as barbaric invaders. ${ }^{50}$ Rurals in that way are stigmatized as the main reason for the degradation of urban life, and the derogative term myrk is often used by urbanites to describe someone who is uncivilized, poorly dressed, aggressive, rude, and intrudes into the urban life-world. ${ }^{51}$ Certainly, "being urban" has become a significant self-identification for the city's longterm residents, but it can also be understood as a defense mechanism directed not so much against newcomers as against the unpredictability and chaos of a changing society that remains unmediated by the state authorities. ${ }^{52}$ Migrants simply become scapegoats for the problems of the new order, especially migrants from Kyrgyzstan's south. ${ }^{53}$

However, migrants are far from a homogenous group: they share different experiences, they have settled in the city at different periods, and they resist the anti-migration discourse, for example, speaking better Russian becomes the marker of difference from the rest of newcomers and elicits better responsesfrom city residents. Many came to Bishkek not just to survive, but to climb the social ladder. ${ }^{54}$ These migrants too perceive themselves differently from migrants living in the poorest illegal settlements (novostroikas) in the outskirts of Bishkek. It is these groups whom Sanghera and Satybaldieva portray as the most vulnerable members of society: they live in difficult conditions, lack access to basic

49 Moya Flynn and Natalya Kosmarskaya, "Constructing the 'Rural Other' in Post-Soviet Bishkek: 'Host' and 'Migrant' Perspectives," Language and Intercultural Communication, 14, no. 3 (2014): $35^{2-368 .}$

$50 \quad$ Philipp Schröder, "Urbanizing' Bishkek: Interrelations of Boundaries, Migration, Group Size, and Opportunity Structure," Central Asian Survey, 29, no. 4 (2010): 453-467; Philipp Schröder "Urban Spaces and Lifestyles in Central Asia and Beyond: An Introduction," Central Asian Survey, 35, no. 2 (2016a): 145-156.

$5^{1} \quad$ Flynn and Kosmarskaya, "Constructing the 'Rural Other' in Post-Soviet Bishkek."

$5^{2}$ Philipp Schröder, "Avoidance and Appropriation in Bishkek: Dealing with Time, Space, and Urbanity in Kyrgyzstan's Capital," Central Asian Survey, 35, no. 2 (2016b): 218-236.

53 Flynn and Kosmarskaya, "Constructing the 'Rural Other' in Post-Soviet Bishkek."

54 Schröder, "Avoidance and Appropriation in Bishkek." 
social services, and feel resentful and angry toward urban wealth and consumption; they also feel ashamed and stigmatized; and they frequently experience ill-treatment from the police. ${ }^{55}$ They are frequently labeled "landgrabers," which delegitimizes them, while the term myrk "others" them. ${ }^{56}$ However, according to Flynn, Kosmarskaya, and Sabirova, despite harsh living conditions in novostroikas, migrants maintain a country-like lifestyle, have strong solidarity relations, and begin to self-consciously criticize the urbanites. ${ }^{57}$

Discourses on the urban-versus-rural divide are entangled with discourses on national identity and nationalism. A Soviet-era vision about the "friendship of people," which is common for urbanites, is juxtaposed against more nationalistic visions of most new and Kyrgyz-speaking residents of Bishkek and Kyrgyz politicians. Andrew Wachtel suggests that despite President Askar Akayev's ideology of "Kyrgyzstan is our common home," the country is shifting from a multi-ethnic paradigm to an ethno-national state that promotes the use of the titular national language and culture and suppresses minorities. ${ }^{58}$ One way to consolidate the Kyrgyz ethnic group is through the creation of symbolic space: Wachtel describes how the figure of Manas-a Kyrgyz national hero said to have united Kyrgyz tribes and conquered others-is fetishized in Kyrgyz monuments, literature, and education.

Cummings also focuses on complex discourses of monuments and buildings in Bishkek as "documents in stone" that have a life of their own..$^{59}$ Monuments reflect public ideology, which draws on national identity both as a set of ideas and as a template for action. Monuments represent the official ideology of elites (political, economic, and cultural); they become their symbolic capital, and they exclude popular participation. Her analysis of the evolution of monuments from Lenin to Erkindik to Manas in the Ala-Too square in the center of Bishkek shows how the national ideology of the Kyrgyz elite is transforming from internationalism to nationalism, and how it is shaped by both the wider transnational political links (e.g., with Russia) and the local perceptions of Kyrgyz statehood. Suyarkulova interprets such contemporary processes of

55 Balihar Sanghera and Elmira Satybaldieva, "Ethics of Property, Illegal Settlements, and the Right to Subsistence," International Journal of Sociology and Social Policy, 32 no. 1/2 (2012): 96-114.

$5^{6}$ Sanghera and Satybaldieva, "Ethics of Property, Illegal Settlements, and the Right to Subsistence."

57 Flynn, Kosmarskaya, and Sabirova, "The Place of Memory."

$5^{8}$ Andrew Wachtel, "Kyrgyzstan between Democratization and Ethnic Intolerance," Nationalities Papers, 41, no. 6 (2013): 971-986.

59 Sally Cummings, "Leaving Lenin: Elites, Official Ideology, and Monuments in the Kyrgyz Republic," Nationalities Papers, 41, no. 4 (2013): 6o6-621. 
constructing a Kyrgyz national identity as myth-making. ${ }^{60}$ She shows how the search for a coherent national identity in post-Soviet Kyrgyzstan leads to the re-emergence of patriarchal norms and the projection of ideas for what is "proper" Kyrgyz masculinity and femininity in society.

Yet, these multiple binary divisions between Soviet and post-Soviet, between urbanites and newcomers, Kyrgyz and Uzbeks, national and international have been already been criticized because they enforce a traditional transitology perspective on Central Asia and do not account for the more complex urban realities of our times. Ibañez-Tirado criticizes the transition, post-socialism, and post-colonialism perspectives on Central Asia and proposes the need to rethink Soviet and post-Soviet. ${ }^{61}$ In her article, "How Can I be Post-Soviet if I Never was Soviet?", she suggests that there would be no such strict division in the narratives of people. Alternative temporalities, described as lived and subjective time, help to escape such static historical chronology and teleological temporaneity. Sgibnev and Vozyanov focus on mobility in order to overcome a transitology-influenced view that is based on hierarchical frames of reference. ${ }^{62}$ Liu portrays history as a nonlinear presence in social imaginaries and as spatiality defined by multiple dependencies: from the micro-scale of situated worlds to the macro-scale of national and transnational orders. ${ }^{63}$ He shows that although duality - in his case between preserving the Uzbek way of life in Osh and an orientation toward progress - is an important way of thinking about this city, the real situation is much more complex: the old and the new interpenetrate, and boundaries between the two are at least blurry. Eventually, Liu suggests that Osh is not so much a tale of two cities, but a tale of a mediating cityscape-a city of evolving relations.

Schröder suggests moving beyond the nostalgic discourse of Soviet Frunze as green, cozy, predictable, and not densely populated versus Bishkek as bar$d a k$, disorder, and becoming ruralized. ${ }^{64}$ On the one hand, he describes the new urban middle-class subjectivities attached to multiple modernities that celebrate Kyrgyz culture and nature with the amenities of civilization, thus blurring the boundaries between rural authenticity and urban progress. On the

\footnotetext{
6o Suyarkulova, "Fashioning the Nation."

61 Diana Ibañez-Tirado, "How Can I Be Post-Soviet if I Was Never Soviet?' Rethinking Categories of Time and Social Change-A Perspective from Kulob, Southern Tajikistan," Central Asian Survey, 34, no. 2 (2015) 190-203.

62 Wladimir Sgibnev and Andrey Vozyanov, "Assemblages of Mobility: The Marshrutkas of Central Asia," Central Asian Survey, 35, no. 2 (2016) 276-291.

63 Liu, Under Solomon's Throne.

64 Schröder, "Avoidance and Appropriation in Bishkek."
} 
other hand, he describes how the term myrk is a "diagnosis, not a verdict," i.e., a temporary condition of a liminal personae whose body and everyday behavior are disciplined to synchronize with the city flows. The condition of liminality is also well described by Osmonova as betwixt-and-between, a state of suspense, neither here nor there. ${ }^{65}$ However, her analysis of newcomers' experiences in Astana shows that liminality is not necessarily a positive condition, but may be taken as being stuck in a transitional phase not of liberation, but of constraint, alienation, and a loss of home.

In our work, we also try overcome the binary division of time into Soviet and post-Soviet frames of references by bringing in new subjectivities, sociabilities, and conceptualizations of urban space. One such way to develop an alternative focus beyond the Soviet/post-Soviet comparison is to engage deeper with the uniqueness of local context and local processes. One important question that we ask is: What makes Bishkek different from other Central Asian cities? The first answer that comes to mind is: Bishkek is the city of two revolutions. Kyrgyzstan, with different degrees of skepticism, has been portrayed as the "island of democracy," while Bishkek often is portrayed as its hotbed of political unrest and civil activism. It is a city where two political regimes were taken down by civil unrest, and it is home to hundreds of international and local nongovernmental organizations and various social activist groups: from Marxists and feminists to Islamic activists and hardcore Kyrgyz nationalists. Understanding the nature of activism in Bishkek can help us recreate the more complex picture of urban relations and dynamics beyond simple binaries.

\section{Bishkek: The City of Two Revolutions}

Important questions asked by many analysts are: How genuinely democratic were the Kyrgyz revolutions and what was the role of Bishkek in them: the place of their origin or simply the arena where everything was orchestrated? Juraev notes that the Tulip Revolution of 2005 attracts a range of interpretations: from democratic revolution to regime change or merely a transfer of power. ${ }^{66} \mathrm{He}$ argues against several propositions that perceive Kyrgyzstan as the island of democracy and the revolution as truly democratic. Instead, he explains revolution as a product mainly of the political power struggle between clans, not between ideas. In his view, it is the tribal and localistic

65 Kishimjan Osmonova, "Experiencing Liminality: Housing, Renting and Informal Tenants in Astana," Central Asian Survey, 35, no. 2 (2016): 237-256.

66 Shairbek Juraev, "Kyrgyz Democracy? The Tulip Revolution and Beyond," Central Asian Survey, 27, no. 3/4 (2008): 253-264. 
competition that explains political pluralism and opposition, yet this is not a path to democracy because the groups involved follow informal rules and not those outlined in the constitution. Cummings argues that the revolution of 2005 will be remembered ambivalently because of its negative consequences, such as widespread looting and disappointed expectations. ${ }^{67}$ Cummings and Ryabkov refer to Radnitz, who does not regard the revolution as an urban phenomenon as it was initiated in the rural areas and a majority of participants were mobilized there. ${ }^{68}$ Temirkulov develops a similar argument; namely, that not only were most participants of rural origin, but also that the mechanisms of mobilization were rural as well: aksakals (respected elderly people), tooganchilik (support of relatives and kinship networks), palvans (strong young men), and kurultai (traditional gathering). ${ }^{69}$

In contrast, the revolution of 2010 is described differently. Temirkulov proposes that in the 2010 revolution, mobilization was not organized, but it was more of a spontaneous collective action. ${ }^{70}$ It lasted only two days (versus one month in 2005) and material incentives were not as much in play. He suggests accordingly that this revolution was brought about by people and not by opposition leaders, since the latter had been arrested already the night before. He also points to the specific role played by telecommunication: mass media and the internet were crucial in steering collective action. Nora Williams shows that in 2010, there were five times more internet subscriptions than in 2005 and that this influenced the second revolution to be more "bottom-up" than the first one. ${ }^{71}$ In her opinion, information and communications technology contributed not so much to direct participation, but to more people joining as observers and transmitters of events. It is this mass broadcasting that, according to Williams, made the events feel real and immediate.

The role of the internet, mobile technologies, and social media deserves special attention in the discussion of urban activism in Bishkek. Ibold refers to McGlinchey and Johnson to show how activist networks use new media to challenge authoritarian control and as a new forum to express alternative

67 Sally Cummings, “Introduction: 'Revolution' Not Revolution," Central Asian Survey, 27, no. $3 / 4$ (2008): 223-228.

68 Sally Cummings and Maxim Ryabkov, "Situating the 'Tulip Revolution," Central Asian Survey, 27, no. $3 / 4$ (2008): 241-252; Scott Radnitz, "What really happened in Kyrgyzstan?," Journal of Democracy, 17, no. 2 (2006): 132-146.

69 Azamat Temirkulov, "Informal Actors and Institutions in Mobilization: The Periphery in the 'Tulip Revolution', Central Asian Survey, 27, no. 3/4 (2008): 317-335.

70 Azamat Temirkulov, "Kyrgyz 'Revolutions' in 2005 and 2010: Comparative Analysis of Mass Mobilization," Nationalities Papers, 38, no. 5, (2010): 589-6oo.

$71 \quad$ Nora Williams, "Observing Protest: Media Use and Student Involvement on 7 April 2010 in Bishkek, Kyrgyzstan," Central Asian Survey, 34, no. 3 (2015): 373-389. 
opinions. ${ }^{72}$ This is particularly relevant for youth. In Bishkek, new media has become more and more embedded into the everyday life of young people, affecting their identity-formation, which becomes more fluid, unpredictable, and less dependent on strictly local realities. Ibold shows how new media creates novel forms of connectivity: for contacts with people outside of Kyrgyzstan and for communication within the country.

As part of our criticism of binary divisions, it is interesting to note here that the internet enables young people to create "more complex and fluid allegiances," ${ }^{\prime 3}$ thereby challenging cultural divides and other previously assumed certainties (e.g., the regional North-South distinction within Kyrgyzstan, the urban-rural divide, or the one between modern and traditional mindsets). The role of social media is particularly crucial in this context, where, despite all democratic claims, official and print media remain under tight control. Kurambayev argues that Kyrgyzstan is one of the most oppressive countries in regard to free media. ${ }^{74}$ According to him, government officials, politicians, and influential businessmen attack Kyrgyz journalists in several ways: court cases and lawsuits, physical attacks, arbitrary detention, blacklisting, and threats. Because of such victimization, many journalists turned to avoidance strategies and self-censorship, such as tamed criticism, circumventing controversial political topics, or criticism of the abstract system, but not of particular individuals. ${ }^{75}$

People on the streets, however, are not as silent. Since the revolution of 2010, Kyrgyzstan and Bishkek have witnessed massive waves of protests. Table 1 shows the increase from 2010 to 2013.

On average, half of all protests took place in Bishkek. Over four years, the number of protests in the city exceeded 2,00o, which brings the average to almost 1.4 protests a day. The statistics for the country show that a majority (59 percent) of these protests had political goals. However, the number of protests with socioeconomic demands was also quite high -41 percent. Many of these socioeconomic protests were organized by internal migrants who had recently relocated to Bishkek-residents of "new settlements" (novostroikas) who frequently picketed in front of the government headquarters and blocked

72 Hans Ibold, "Disjuncture 2.0: Youth, Internet Use and Cultural Identity in Bishkek," Central Asian Survey, 29, no. 4 (2010): 521-535. McGlinchey and Johnson, "Aiding the Internet in Central Asia," Democratization, 14, no. 2 (2007): 273-288.

73 Ibold, "Disjuncture 2.o."

74 Bahtiyar Kurambayev, "Journalism and Democracy in Kyrgyzstan: The Impact of Victimizations of the Media Practitioners," Media Asia, 43, no. 2 (2016): 102-111. Kurambayev, "Journalism and Democracy in Kyrgyzstan." 


\begin{tabular}{|c|c|c|c|c|c|c|}
\hline \multirow[b]{2}{*}{ Year } & \multicolumn{3}{|l|}{ Kyrgyzstan } & \multicolumn{3}{|c|}{ Bishkek } \\
\hline & $\begin{array}{l}\text { Number of } \\
\text { protests }\end{array}$ & $\begin{array}{l}\% \text { of } \\
\text { political } \\
\text { protests }\end{array}$ & $\begin{array}{l}\text { \% of socio- } \\
\text { economic } \\
\text { protests }\end{array}$ & $\begin{array}{l}\text { Number of } \\
\text { protesters }\end{array}$ & $\begin{array}{l}\text { Number of } \\
\text { protests }\end{array}$ & $\begin{array}{l}\% \text { of } \\
\text { protests }\end{array}$ \\
\hline 2010 & 685 & $76 \%$ & $24 \%$ & 38,000 & 259 & $38 \%$ \\
\hline 2011 & 1193 & $5^{2 \%}$ & $47 \%$ & 38,000 & 582 & $49 \%$ \\
\hline 2012 & 1286 & $46 \%$ & $54 \%$ & 73,000 & 726 & $56 \%$ \\
\hline 2013 & 849 & $61 \%$ & $39 \%$ & 119,000 & $45^{2}$ & $53 \%$ \\
\hline Total & 4013 & $59 \%$ & $41 \%$ & 268,000 & 2019 & $50 \%$ \\
\hline
\end{tabular}

SOURCE: “KYRGYZSTAN BUZIASHCHII," DELO NO. 1: RESPUBLIKANSKAIA GAZETA, APRIL 17, 2014. ACCESSED DECEMBER 26, 2016. HTTP://DELO.KG/INDEX.PHP/HEALTH-7/7138-KYRGYZSTAN -BUZYASHCHIJ.

roads. Their main demands were directed at the improvement of the physical infrastructure and the socioeconomic conditions in their settlements. ${ }^{76}$

In the protests over land and infrastructure, we see how space becomes politically relevant. Nasritdinov, Zhumakadyr kyzy, and Asanalieva have shown how the roots of conflicts over land can be detected in the corruption practices of Bishkek's municipality and architecture department. ${ }^{77}$ Kaganova, Akhmetov, and Undeland analyze similar questions. ${ }^{78}$ They describe how, according to the constitution, land is classified into state, municipal, and private. Land that is not classified is principally considered to be municipal. Since the 199os, the Bishkek municipality has been engaged in selling this unclassified land to private individuals. These transactions often conflict with the law: land is allocated to private owners without a bidding process, without specifying the exact type of use, land reserved for "public use" is sold, and sometimes land

76 Nasritdinov, Zhumakadyr kyzy, and Asanalieva, "Myths and Realities of Bishkek's Novostroikas", in Laruelle (ed.) Kyrgyzstan beyond 'Democracy Island' and 'Failing State': Factoring Social and Political Challenges in a Post-Soviet Society, M.E.Sharpe, 2015.

77 Nasritdinov, Zhumakadyr kyzy, and Asanalieva, "Myths and Realities of Bishkek's Novostroikas", in Laruelle (ed.) Kyrgyzstan beyond 'Democracy Island' and 'Failing State': Factoring Social and Political Challenges in a Post-Soviet Society, M.E.Sharpe, 2015.

78 Olga Kaganova, Abdirsaul Akmatov, and Charles Undeland, "Introducing More Transparent and Efficient Land Management in Post-Socialist Cities: Lessons from Kyrgyzstan," International Journal of Strategic Property Management, 12, no. 3 (2008): 161-181. 
is sold to several owners resulting in conflicting claims. Various corruption schemes are present: for example, land is sold for informal payments at market prices, while formal payment is minimal, or elites in power simply grab the land from the municipality. ${ }^{79}$

This explains how certain elites got hold of many former industrial sites and buildings in Bishkek. ${ }^{80}$ Spector and Botoeva analyze how owners of smallscale sewing businesses rent space inside such former industrial sites because the latter do not suffer from electricity blackouts, which are common in other parts of the city and can disrupt the workflow. The new owners of industrial buildings, who lease their spaces, are primarily interested in making profit, so they do not invest into renovation and regularly increase the cost of rental. This leads to a variety of resistances by renters, including protests and the development of exit strategies. The authors argue that the political dynamics of ownership and politics of space are connected and that space becomes political through human practices. Thus, urban change is not politically neutral, but becomes embedded in sociopolitical transformations. ${ }^{81}$

The discussion of land and property is strongly politicized by Sanghera and Satybaldieva. ${ }^{82}$ They advocate for a moral responsibility approach to property, based on the understanding that access to land and resources is vital for securing human capabilities and that moral sentiments motivate individuals to take responsibility for their own and others' well-being. Land is embedded with moral rights, and there should be moral limits to its privatization. The state and influential groups should not deprive poor individuals of their basic necessities, and, if land is not fairly distributed, poor people have a right to grab it. In conclusion, Sanghera and Satybaldieva defend the right of internal migrants to occupy land in Bishkek's novostroikas. They perceive such occupation not as "spasmodic, irrational, visceral," but as a "moral claim to necessity" moved by "moral sentiments of anger, indignation, resentment, betrayal."

In Bishkek, it is common to hear the expression "Kyrgyzstan strana otkrytykkh vozmozhnostei" (Kyrgyzstan is a country of many opportunities). In practice, this might as much refer to opportunities of circumventing the law, and we have been presented with considerable evidence of people, especially those from the higher levels of the local hierarchy, making use of such illicit

79 Kaganova, Akmatov, and Undeland, "Introducing More Transparent and Efficient Land Management in Post-Socialist Cities."

8o Regine Spector and Aisalkyn Botoeva, "New Shop Owners in Old Buildings: Spatial Politics of the Apparel Industry in Kyrgyzstan," Post-Soviet Affairs, (2016) http://dx.doi.org/10. 1080/1060586X.2016.1251024.

81 Spector and Botoeva, "New Shop Owners in Old Buildings."

82 Sanghera and Satybaldieva, "Ethics of Property, Illegal Settlements, and the Right to Subsistence." 
opportunities. Of course, the political and economic elites of other Central Asian countries (Kazakhstan, Uzbekistan, Tajikistan, and Turkmenistan) have no less actively abused their countries' resources for their private enrichment, but only in Kyrgyzstan do we see how people from the bottom of the local hierarchy can also actively engage in a contest for their fair share of resources.

What is important for our collection of articles is that these activist endeavors tell much about Bishkek's uniqueness. It is hard to imagine Astana, Tashkent, Dushanbe, or Ashkhabad to have two revolutions over a quarter of century and 500 protest activities per year. Even if there were any potential for social activism in these other Central Asian capitals, they are still in a very embryonic form. In Kyrgyzstan, and especially in Bishkek, however, we see how over the years, the practices of social activism have been evolving and took more meaningful and organized forms; today, we can observe all kinds of activist groups and movements that are not simply struggling for resources, but feature solid ideological foundations and concrete visions. In the following section, we provide a brief overview of some main directions, in which contemporary social activism in Bishkek is developing.

\section{Social Activism in Bishkek}

In this section, we describe how "quantity turns into quality" and how social activism that might have had rural origins slowly may become a part of everyday life in the capital of Kyrgyzstan. Specifically, we review three active groups selected in part due to the authors' personal contacts with group members and participation in their activities. We begin with one of the oldest groups, which began its social activities in the late 1980s-the artists and architects of the Studio Museum.

\section{Studio Museum, Theater 705, and Bishkek's Artistic Underground}

In 1987, the architectural Studio Museum organized an exhibition entitled "Parallel City." It explored ideas, forms, and discourses that were inspired by official ideologies and informal everyday narratives. After a series of exhibitions, studio director Ulan Japarov came up with a new format: April $1^{\text {st }} \mathrm{Com}-$ petitions. The uniqueness of the April $1^{\text {st }}$ genre was that on this day of "fools" and jokes, ideas could be expressed with much greater freedom and traditional artistic, political, and cultural limits could be significantly stretched. Participation in these exhibitions was open to anybody beyond the artists' and architects' circles, and any media was allowed. By early 2017, 12 competitions had been held, with participants and ideas originating from across Central Asia and beyond. Each year focused on a unique theme: 
- 2003-Chainiki (Teapots)

- 2004-Kalpak (Kalpak - the traditional Kyrgyz hat for men)

- 2005-Konkurs stoyachi noskov (Standing socks competition)

- 2006-Avtoportret "v nature" (Self-portrait "in nature")

- 2009-Istoriya bolezni (History of illness)

- 2010-Reklamnaya pauza (Advertisement break)

- 2011-samuchitel' $K G$ (Self-teaching manual KG)

- 2012-Putevoditel' po Tsentral'noy Azii (Travel guide on Central Asia)

- 2013-Vse pod rukoy (All at your fingertips)

- 2014- $\mathrm{Za}]$ Hod konem (Knight's move)

- 2015-Kasting na vozhdya (Casting for a leader)

- 2016-Taburet (Stools)

Photos 1, 2, and 3 illustrate the often overt political messages that could be delivered in this artistic form.

The composition by Zitta Sultanbaeva and Ablikim Akmulaev titled "New Green Tea" (Photo 1) points to the controversy regarding the us military base located at the Manas airport in Bishkek at the time.

Podkabluchnik in Russian means someone who is ruled by his wife (Photo 2). Whether or not the contributors from Kazakhstan were trying to make a deliberate point, some attendees read the installation as indirect slap at thenPresident Askar Akayev. In his later years in power, the conventional wisdom

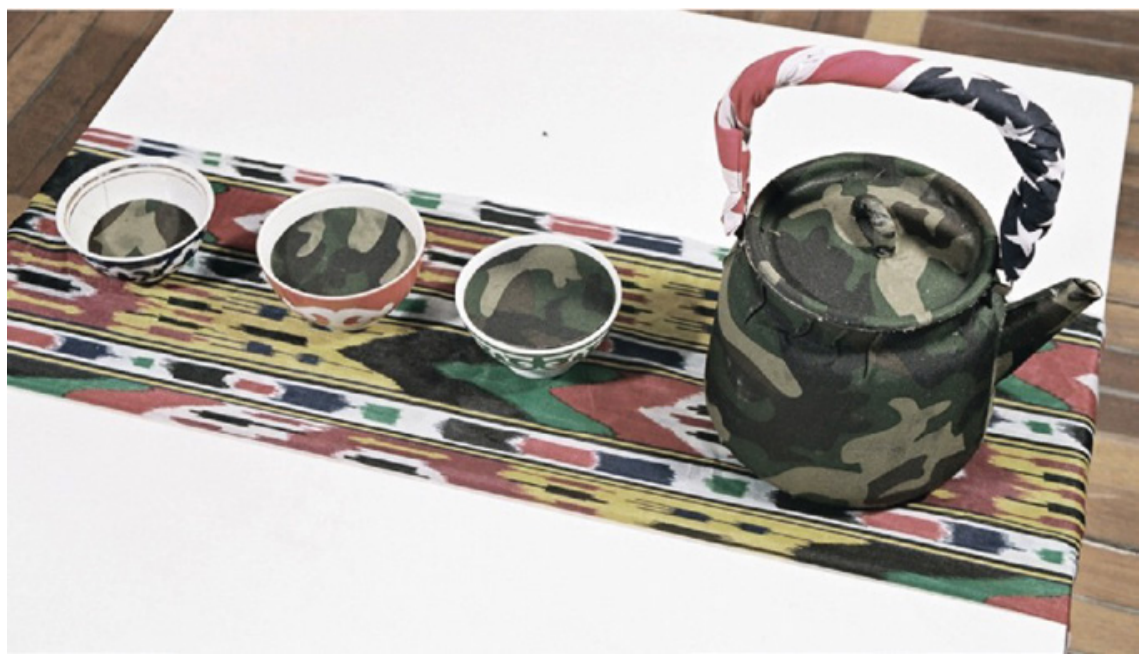

рното 1 Zitta Sultanbaeva and Ablikim Akmulaev: New green tea (2003: Chainiki) 
held that his wife, Mairam Akaeva, was actually ruling the country through him.

In the triptych "Bureaukratistan, Looterstan, and ?" (Photo 3), Ernst Abdrazakov and Dilya Khalmurzina develop a critical perspective on the 2005

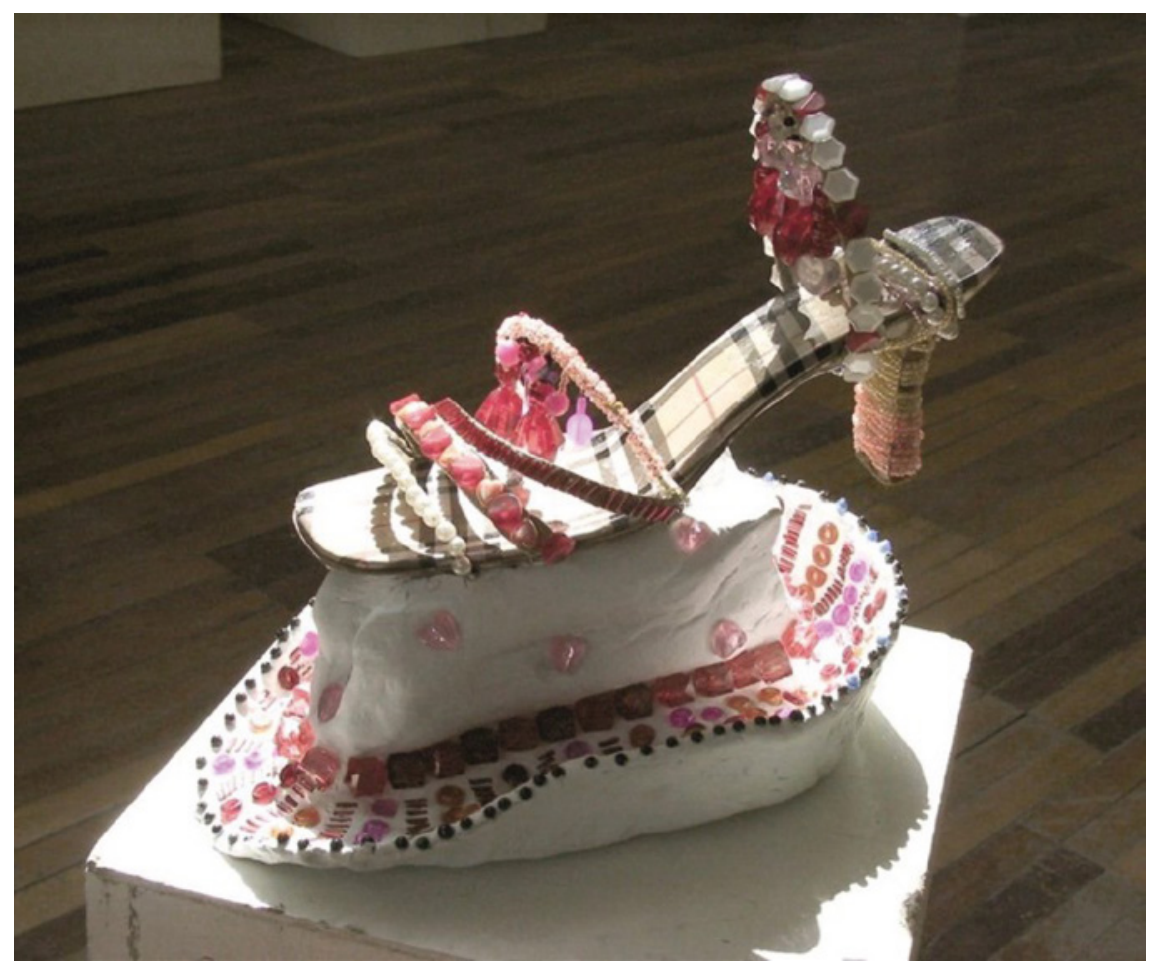

рното 2 GaBo Kussainovs: Kalpak podkabluchnika (2004: Kalpak)

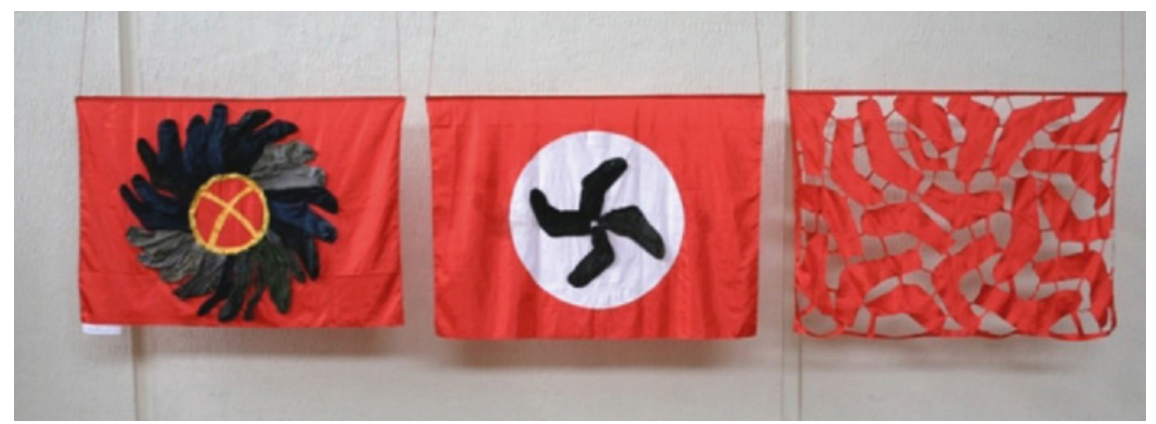

рното 3 Ernst Abdrazakov and Dilya Khalmurzina: Bureaucratistan, Looterstan, ? (2005: Standing socks) 
Revolution. In the first image, the 40 rays around the sun on the Kyrgyz flag representing 40 Kyrgyz tribes are replaced by 40 socks fighting for power. In the second image, four socks form a swastika representing the post-revolutionary chaos, violence, and looting. The final image of the series depicts the overall confusion about where to go after the dust has settled.

In Photo 4, Aibek Mailybashov used Adobe Photoshop to portray himself as the president of Kyrgyzstan. The key message: Every Kyrgyz thinks that he deserves to be the president. This work proved quite prophetic, as indeed five years later, in 2011, more than 80 people put their names forward as candidates for the presidency.

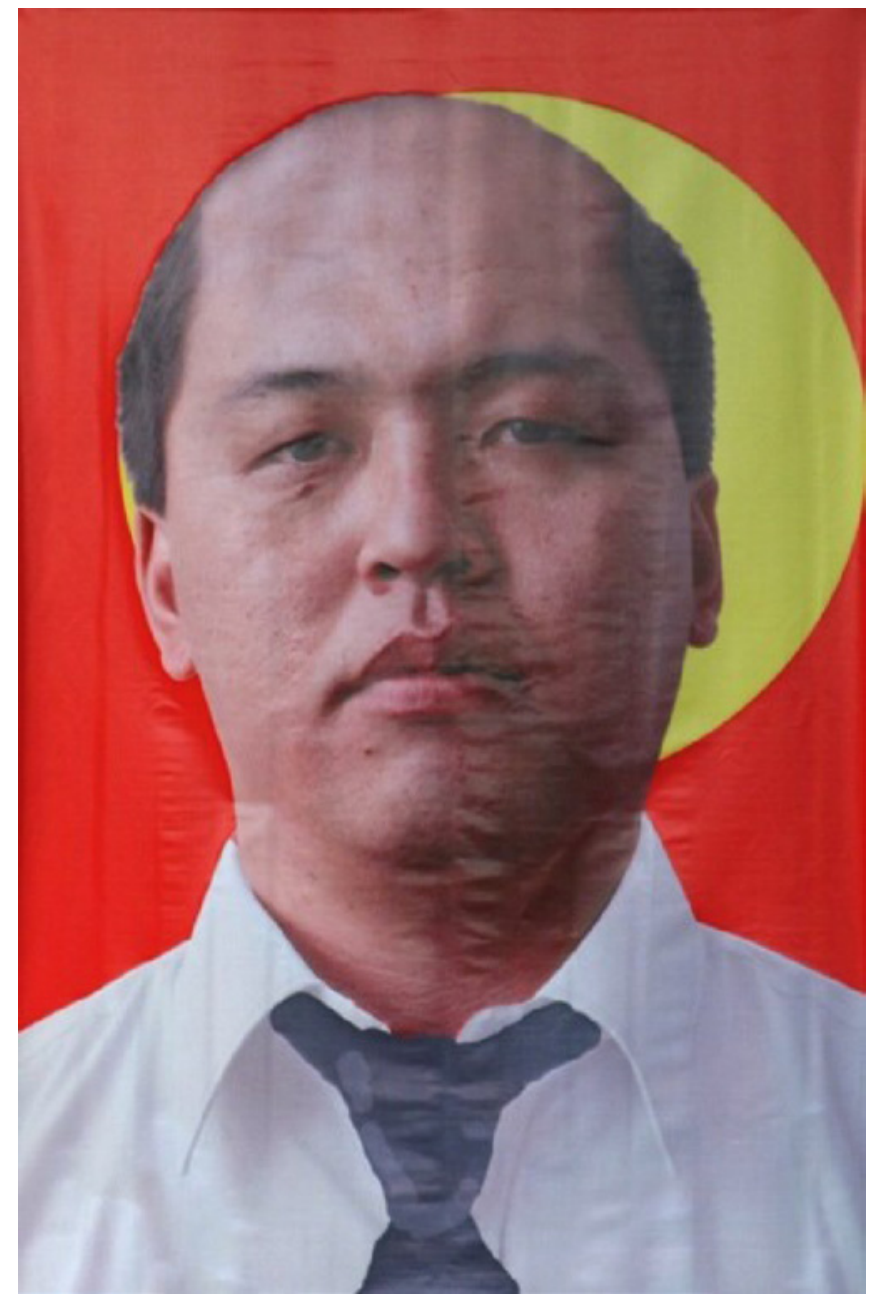

Рното 4 Aibek Mailybashov: I am the President (2006: Self-portrait "Vnature") 

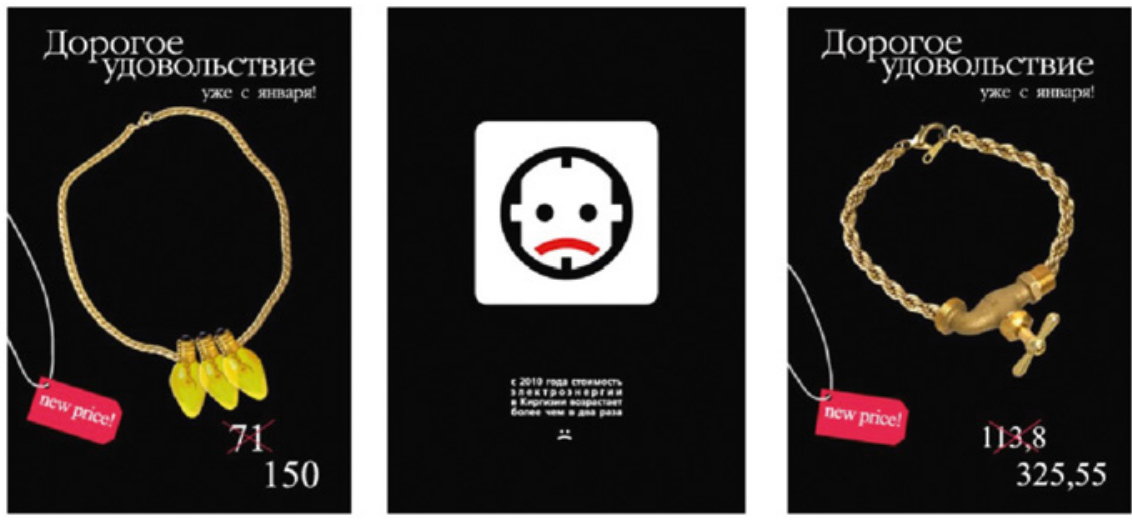

Рното 5 Alexey Lysogorov: Expensive pleasure (2010:Advertisement)

Finally, Photo 5 is a work by Aleksey Lysogorov entitled "Expensive Pleasure." It shows the increased prices for electricity and water in Kyrgyzstan. It is believed that this increase of consumer prices by then-President Kurmanbek Bakiyev's family in January 2010 pushed the population's patience to the breaking point and thus significantly contributed to the emergence of a revolution. Interestingly, this and many other artworks that were strongly critical of Bakiyev and his family turned to be quite prophetic as well. In fact, this exhibition took place on April 1, 2010; one week later, on April 7, Bishkek experienced its second revolution within five years.

According to the art critic Gamal Bokonbaev, the April $1^{\text {st }}$ exhibitions were authentically informal. They became a form of social art, which was a real vanguard for the country. Besides exhibitions, Ulan Japarov published two literary almanacs: Urbi-et-Orbi and Kurak. These included not only artworks, but also artistic texts by writers from all over the region. The last issue, published in 2011, was entitled "Martian Chronicles" and included a complex geopolitical discourse on Central Asia as terra incognito being colonized by various "alien" forces; the resulting intersection, hybridization, and collage of different cultures, and traditions; and the reemergence of various local archaic forms.

As time went by and Japarov got older, his activism decreased. Today, he is trying to pass on his legacy to the younger generation. Among those willing to take over are a young architect, Meder Akhmetov, and a group titled Theater 705 and lead by Marat Raimkulov. In 2015 and 2016, the April $1^{\text {st }}$ exhibitions were organized and conceptualized by the two of them. Theater 705 rents the basement of an old Soviet residential building in the city center where they also held their exhibitions. So, in some way, this circle quite literally became Bishkek's artistic underground. Interestingly, among the participants in the 
2016 underground exhibition last year was Aliya Shagieva-a talented young artist who happens to be the daughter of current President Almazbek Atambayev. Beyond the symbolism, this fact alone tells a considerable amount about the complex layers of Bishkek's activism.

\section{STAB Queer-Communists}

The freedom of Bishkek attracts creative people not only for short-term exhibitions, but also for long-term residence and forms of activism that are impossible in other Central Asian countries. STAB was established in 2012, and originally its acronym stood for the School of Theory and Activism Bishkek. In 2016, it was changed into Shkola Tvorcheskoy Aktualizatsii Budushchego (School for the Creative Realization of the Future) reflecting, perhaps, the heavier emphasis on the construction of utopian visions. While the official director of STAB is local, two of the creative directors, who are also key ideologists, are not from Kyrgyzstan: Georgy Mamedov is from Tajikistan and Oksana Shatalova is from Kazakhstan. Lectures organized by sтAв also feature many interesting speakers from other countries.

Members of the group call themselves queer-communists. Their ideological platform is based on a radical leftist vision. The prefix "queer" implies the critique of static, fixed, essentialist concepts of identity, like race, ethnicity, and gender. In STAB's vision, there are many identities, and SтAB is a project that unites them. For example, many STAB members are atheists, but their queeroptics position them against the prohibition of wearing the hijab in public. STAB activities focus on the intersection of art, literature, research, and activism. The school has strong theoretical foundations and devotes significant amounts of time to the conceptualization of their work. Since its establishment, АтАв has organized a large number of lectures, workshops, and thematic short-term courses. They also published two large volumes: Vernut Budushee (Back to the Future) and Bishkek Utopicheskii (Bishkek Utopian) and produced several series of animations and videos.

Table 2 lists some of the major umbrella themes that the group has worked on. In addition, there were many individual lectures, conferences, and symposia held at the Sтав office in central Bishkek, in the Kyrgyz National Museum of Arts, at the American University of Central Asia, and other places.

However, STAB is more than a theoretical platform for debating. The group is also engaged in several activist practices in Bishkek. One of the most successful cases was their work with the Soviet mosaics on the walls of various public and residential buildings. STAB perceives these as examples of a very important cultural heritage - a form of art that is public and belongs to people, not only to the new buildings' owners. They cataloged all of these mosaics, created a 


$\begin{array}{ll}2012 & \text { Gender literacy campaign; } \\ & \text { Consciousness and production; } \\ & \text { Critical animation workshop 1: } \\ & \text { Russian language in Kyrgyzstan; } \\ & \text { Critical animation workshop 2: Who are you with?; } \\ & \text { Critical animation workshop 3: } \\ & \text { Critique and norm; } \\ & \text { Back to the future; } \\ & \text { Utilization of the socialist city as commons; } \\ & \text { Artistic practices of inclusion; } \\ & \text { Bishkek: Chronicles of radical imagination; } \\ & \text { Critical animation workshop 4: } \\ & \text { Mythologies; } \\ & \text { Understanding the Soviet in Central Asia; } \\ & \text { Bishkek utopian; } \\ & \text { Soviet popular science films and literature; } \\ & \text { Queer-communism is ethos; } \\ & \text { Against nature. }\end{array}$

SOURCE: SHTAB, KHRONIKA OSNOVNYKH SOBYTII. ACCESSED DECEMBER 27, 2016. HTTP://WWW. ART-INITIATIVES.ORG/RU/CONTENT/HRONIKA-OSNOVNYH-SOBYTIY.

map showing their locations, and now organize walking tours. While searching for Bishkek's mosaics they came across a building owned by the karaoke club Zapoi, which had an important mosaic titled "Cosmos and Scientific Progress" on one of its outside walls. The club owners had tried to disguise the mosaic by painting over it in a dark brown color. STAB filed a complaint, created a critical animated video, and raised public awareness of the endangered mosaic. As a result, the owners were fined and ordered to remove the paint.

STAB also worked to protect Bishkek's Botanical Garden from threats from various developers who want to build residencies there. The Parliament wanted to transfer the Botanical Garden from the Kyrgyz Academy of Sciences to the Ministry of Agriculture in 2016. STAB regarded the shift as the first move toward eventual privatization of the land and cooperated with employees of the Botanical Garden to raise their voice and protest against such transfer.

Mamedov, in his personal interview with one of the authors criticized the contemporary state of activism in Bishkek for its lack of political platform 
and discussion. He believes that most of activism today represents the interests of middle class and long-term residents and that it is quite xenophobic toward the urban poor and internal migrants. Such activism, in his view, is neither critical nor reflexive. He suggests that only the leftist platform can offer a view of the city as a commons and address the needs of the less fortunate. STAB tries to create coalitions: with trade unions, LGBT communities, feminists, the Kyrgyz Museum of Arts, and others. At the same time, STAB frequently criticizes other groups: Mamedov does not see such criticism as something negative, but as an integral part of a necessary discourse. He thinks that it is productive to define contradictions and disagreements, but he does not to want to waste time seeking compromises. This stance seems unfortunate because it may explain why some other activist groups and individuals who used to work with SтАв have now distanced themselves from it. Consequently, this initiative, which three or four years ago was still seen as a very promising movement, has not significantly expanded despite its strong ideological foundations and great conceptual potential.

\section{Urban Initiatives}

One of the people who started with STAB, but later disengaged, was Raushanna Sarkeyeva. She appeared in one of STAB's very first videos-on feminism. However, she later perceived their theoretical approach as too detached from reality and having little impact, so she moved on and in April 2014 established her own activist group called Urban Initiatives. The group's first project was organizing the Bishkek Upgrade Urban Forum, which brought together a large number of activists, experts, architects, and city representatives, including several well-known urban specialists from Russia and Europe. The Forum offered two intensive days of parallel sessions and a competition of urban ideas. The Mayor's Office granted winners financial and logistical support to realize their projects. Ulan Japarov was also among the Forum's organizers, and STAB hosted their own session.

Inspired by the success of the first forum, in 2015 Urban Initiatives organized a similar event in the city of Osh in southern Kyrgyzstan. The Osh Urban Forum was not as successful - it lacked the critical mass of genuinely interested experts and activists. Now the group is preparing for the third forum, scheduled for spring 2017 in the capital. However, this time it is conceptualized differently: called The Forum of Cities, it aims to engage with several cities and smaller towns in Kyrgyzstan. Urban Initiatives is planning to conduct weeklong research/activism projects in five cities and towns prior to the forum; at the time of writing they had just completed research in the city of Tokmok, east of Bishkek. 
Urban Initiatives' first applied research project was on municipal libraries in Bishkek. The city has 28 libraries, but today many are very poorly utilized, and their facilities remain in bad condition. Urban Initiatives carried out extensive research on all of them. They employed a range of research instruments: from surveying the opinions of library users, librarians, and people on the street to GIS mapping and analysis. On the basis of the research report and a public presentation before a large audience, the group came up with two pilot projects for libraries $\#_{13}$ and $\#_{18}$. Some financial support was found to renovate their facilities, and then the group worked with the community toward turning the almost empty libraries into thriving community centers. One year later, their effort had brought some tangible results: these libraries are better attended, hours have been extended, and they regularly host various interesting events. Library \#13 even opened a small coffee shop that serves both library users inside and pedestrians through a small window outside.

Raushanna and her colleagues Aikanysh Derbisheva and Dinara Kanubek kyzy are learning as their projects progress. One interesting project, which they do not believe was very successful, focused on the rehabilitation of abandoned city parks. One illustrative case is that of a park called Sloniki (Elephants) in one of Bishkek's micro-districts. It is located between several residential apartments and features interesting sculptures of various African wild animals. The activists worked with the local residents on repairing and repainting these sculptures, cleaning the park, and organizing community events. Motivated and excited in the beginning, they were disappointed a few months later when they found the park in the same abandoned condition as it was before. Reflecting on the experience, Raushanna suggests that participation can be genuine only when community members realize their own ideas and aspirations instead of those imposed on them by outside activists.

In the summer of 2016, Urban Initiatives organized a three-month long School of Applied Urbanism, which included lectures and workshops by various urban professionals. Participants formed four teams and developed four interesting activist projects. These projects are currently at the implementation stage thanks to support from the Soros Foundation. In addition, Urban Initiatives took part in the week of "Bishkek Partizaning" with activists from Russia, which included a series of informal interventions on redesigning the city.

The three types of activist groups discussed in this section represent different forms of social activism. STAB's activism is very significant; it does not engage in strong protest events, but it provides a powerful leftist ideological platform directed "against" corruption, privatization, middle-class consumerism, and abuse of the public commons. Urban Initiatives, on the contrary, is a 
collective of activists "for" applied change. They do not protest or criticize, but instead develop a more constructive approach working as brokers between urban communities, the city administration, and business representatives. Studio Museum is not so much "against" or "for," but rather "parallel" to the city. They created their own underground artistic scene, where they try to construct a unique alternative space. Besides these three, there are many other groups. The diverse feminist communities and the group Feminist SQ might be the brightest example. One leading activist is Kalicha Umaralieva, a Bishkek activist who for many years has been fighting the sale of public land by the city administration for the construction of high-rise residential buildings in Bishkek. She organized a foundation to take these semi-legal developments to court; and although the group often is not successful, they keep the city administration and developers on their toes. Aibek Baratashvili is another interesting example: he is a Facebook activist with a large number of followers, and he works on various traffic and transport issues. Among his activist projects is collecting money to install pedestrian crossing signs all around the city and installing benches in public spaces. There are many other examples that could be categorized and analyzed. However, the space of this introduction does not allow for that. Instead, we can only repeat once again that social activism in Bishkek is growing and taking a variety of shapes and colors-and this is what makes the capital of Kyrgyzstan truly distinct from other large Central Asian cities.

\section{Activism and Contestation in This Special Issue}

In the previous sections, we dove into the complex ways in which urban space in Bishkek is contested among various interest and activist groups. The collection of articles included in this special issue helps us bring more examples and case studies to further expand this discussion. Five articles touch upon different aspects of contemporary life in Bishkek and reveal interesting urban dynamics.

Philipp Schröder employs multitemporal fieldwork to analyze how claims on places in the city evolve and change over time. It has been eight years since he completed his doctoral fieldwork in one of Bishkek's neighborhoods, which officially is called Iug-2 but has long informally been known as Shanghai. During these years in-between, he kept in touch with his respondents and regularly revisited them once or twice a year. He describes how, prior to 2007, the boys were aligning with their particular yards in contrast to other yards in the same neighborhood, and aimed to violently position their neighborhood over other such youth territorial formations in the adjacent districts. By 2008, they 
were no longer fighting against the boys from other raions, but their new enemies had become the rural (migrant) newcomers to the city. Today, as the boys have matured, married, and engaged in the routines of a "normal" adult life, their territorial claims seem to have disappeared. They still try to meet and play soccer as a group of "Shanghaians" of different ages, yet they are no longer concerned, informed, or involved with the everyday street matters of the neighborhood. Interestingly, they also became indifferent to the relations with rural newcomers as the responsibilities of family and professional life seem to have de-territorialized these young men and dissolved their claims on a spatial identity.

Natalya Kosmarskaya, Artyom Kosmarsky, and Guzel Sabirova recreate another story of how long-term urban residents give up their claims for urban space, specifically the central Ala-Too square in Bishkek. Drawing on their informants' narratives, the authors develop an argument that the loss of space started long before the break-up of the Soviet Union and the arrival of internal migrants. In fact, such processes began in the 1970s when Turdakun Usubaliev, the communist leader of the Kirgiz SSR, decided to redesign the old city center in as a giant square, which to many residents of Frunze seemed too large and impersonal compared with the cozy character of the old central square and its surroundings. The inflow of internal migrants since the 1990s, two revolutions followed by looting, the replacement of the Lenin monument with the national monuments of Erkindik and Manas, the decoration of the square with cheap flowerbeds and fountains, and most importantly, the popularity of the square among rural newcomers - all have further alienated long-term urbanites from the square to a degree that most of them now just try to avoid it. The authors present intriguing insights about how public squares may be perceived as mirroring society, and in that sense the Ala-Too square may very well illustrate the fragmentation, instability, and hybrid nature of Kyrgyz urbanity, trying to merge modernity with tradition.

While urbanites might feel that the city is slowly slipping away, the rural newcomers are very active in claiming it. Craig Hatcher shows how urban property in Bishkek has developed through protest and discontent. He describes how unjust distribution of property during the Soviet times (favoring ethnic Russian professionals and workers) resulted in the formation of the successful Ashar movement in the late 1980 os to fight for the assignment of land and residential space in the capital to young urban Kyrgyz. After the break-up of the Soviet Union, the unfair and corrupted privatization resulted in the impoverishment of a large percentage of farmers and other residents of the rural areas, which triggered their migration to Bishkek in the search alternative incomes. In the city, these groups tapped various channels for obtaining land on the 
urban periphery. The 2005 and 2010 revolutions helped turn the community of internal migrants into a strong political authority that needed to be considered by the government and various other political players. This political authority was exercised to "redefine the inequitable logic of property distribution" via land purchase and occupation. Hatcher does not conclude that the movement for land redistribution would challenge the neoliberal institutions of property and privatization per se; on the contrary, internal migrants aspire to become a legal part of this distribution system. However, this is not their only motivation as a significant part of the discourse that they advance is based on collective moral claims and responsibilities (as was previously discussed by Sanghera and Satybaldieva). ${ }^{83}$

Internal migrants do not only claim new residential areas or established public spaces of Bishkek, such as the Ala-Too square, but also many of the "public interiors." For example, it is easy to notice that the most well-attended cultural events, such as concerts of popular Kyrgyz singers at the Kyrgyz Philharmonic or the Bishkek Sports Palace, are hardly attended by long-term residents of Bishkek but almost exclusively by recent newcomers to the city. In their article, Cholpon Turdalieva and Rene Provis analyze another unique and highly fascinating sociocultural interior space of Bishkek: the toikanas, i.e., special restaurants dedicated to the celebration of various life-cycle events-especially weddings. The authors describe how in the last decade or so, the toikana infrastructure has significantly expanded and diversified: it ranges from very expensive and fancy restaurants, such as the Salkyn-Tor, Ala-Too, or Altyn Kazyna, which can host up to 700 guests, to smaller restaurants in novostroikas for the less well-off families. This novel urban infrastructure and the accelerating ritual practice of conspicuous toi celebrations create a bricolage of regional cultural influences, which adds to the city's hybridity and multi-facetedness. In fact, these celebrations assemble a diversity of interior designs, culinary menus, and artistic performances that display the connectedness of traditional Kyrgyz practices with global trends of fashion, music, and public consumerism.

In the last article of this collection, Emil Nasritdinov analyzes one more form of urban claiming that strongly emerged into Bishkek's public spaces and discourses in recent history: that of religion. Starting with the billboard controversy about Muslim versus Kyrgyz traditional ways of veiling and dressing in the summer of 2016, he describes how various religious practices have become more visible in the streets of the city and how that results in new public debates and forms of contestation. These discourses are formally structured around the conceptualizations and practices of secularism, Kyrgyz national

83 Sanghera and Satybaldieva, "Ethics of Property, Illegal Settlements, and the Right to Subsistence." 
identity, and security, but they are also strongly connected with newer and older gender normativities and subjectivities. Nasritdinov reveals how the competition between secular and religious leaders to interpret the meaning of the hijab-Islamic female headscarf-in fact reflects strong patriarchal stereotypes, with both sides claiming to know what and how women should dress. However, Muslim women in Bishkek really do not need fashion advice. In fact, we can identify a very strong Islamic female activist movement in the city, and all freedoms that this movement has achieved result from their continuous and well-organized struggle, which men had very little to do with. The momentum that this movement has built up enables them to overcome the patriarchal burdens and obstacles, while their new Islamic styles and practices contribute to the cosmopolitan character and contingent diversity of Bishkek.

As we can see from the brief reviews of all these accounts, it is not so much its architecture or urban physicality that makes Bishkek a unique Central Asian city, but its resident personalities and communities, or, to be precise, the brave contestations and numerous claims that cannot be found in other Central Asian urbanities. From that angle, the activist opportunities that have emerged in an environment of less-authoritarian disregard for matters of urban change by city and government authorities could be seen as an important resource to build on. In the concluding section of this introduction, we return to some theoretical concepts outlined at the beginning to see how the case of Bishkek might fit into the practices of contestation and activism in other urban settings outside of Central Asia and the post-Soviet space.

\section{Conclusion}

Bishkek can be described as a divided city. It is divided along multiple boundaries: Soviet and post-Soviet, Kyrgyz and Russian, urban and rural, national and international, wealthy and poor, religious and secular. These divisions and boundaries are both real and imaginary: they can be experienced, embodied, and observed, and they are also strongly present in the narratives and urban experiencing of Bishkek residents.

Bishkek is also a fragmented city: we can see how new elite housing is built as gated communities inside regular micro-districts, and how very poor houses made of adobe bricks find themselves in the middle of wealthy new settlements with fancy two- or three-story residences. This resembles in crass vividness the simultaneous shortening of physical distances and the increase of socioeconomic gaps.

However, just as Fincher and Jacobs argue, these multiple vectors of difference are so intertwined and re-assembled in other spaces and times that it is 
impossible to conclusively separate them from each other. ${ }^{84}$ Accordingly, Bishkek residents have just as many boundaries across which they are connected as that serve to separate them. As time passes, many of these divisions, which were strongly visible in the late Soviet and early post-Soviet periods, become rather fuzzy, if not completely unnoticeable. One could thus argue that the citizens "have moved on," and therefore many of the Soviet/post-Soviet discourses have been rendered unintelligible or even irrelevant. Perhaps it would be fair to say that Bishkek, across its turbulent history of recent revolutions, has been gradually moving from an environment of negative differentiations to one of positive diversity?

One reason for that might be the comprehensively dynamic character of Bishkek's urban fabric, including sociocultural, economic, political, and physical aspects. Out of all Central Asian capitals, Bishkek thus may be the most deserving of Doreen Massey's view of urban space as alive, growing, and evolving on the basis of the social (activist) relations among its polyphony of urban actors. What the likes of Ashgabat, Astana, Dushanbe, and Tashkent feature in more glamorous buildings and cleaner streets, they lack in opportunities for urban activism and, consequently, a citizenry enabled to strive for their right to the city. In many ways naïve and provincial, yet sincere and brave, Bishkek and its residents engage with their urban spaces, with the (critical) performance of their state and with each other, claiming adequate leeway for themselves and their communities.

As time goes by, these claims and struggles have become more meaningful and informed by global trends in social activism. Internet connectivity and the relatively unpatrolled space of social media help local activists to both learn about activists' movements elsewhere and to adapt them locally. This, as we tried to show in this introduction, definitely is not a simple process of copyand-paste, but it is "real" local actors turning global activist visions (Marxism, queer-communism, cultural activism, the Cittaslow movement, etc.) into unique Bishkek activist practices and events.

Lewis Mumford, in his description of democracy in ancient Athens, argues that Greeks killed democracy when Plato placed it on the pedestal and started propagating it. ${ }^{85}$ This certainly is not the intention for this collection of articles. If anything, we perceive the relative degree of freedom in Kyrgyzstan, compared with other Central Asian capitals, not as something to boast about, but as something to appreciate, value, and further build upon.

\footnotetext{
84 Jacobs and Fincher, "Introduction."

85 Lewis Mumford, The City in History: Its Origins, Its Transformations, and Its Prospects (New York: Mariner Books, 1968).
} 